\title{
TB and HIV among hill tribe marginalized vulnerable population, Thailand
}

\author{
Tawatchai Apidechkul \\ From 17th International Symposium on HIV and Emerging Infectious Diseases (ISHEID) \\ Marseille, France. 23-25 May 2012
}

\section{Introduction}

Since 1982, Thailand had been reported 372,874 cases of HIV/AIDS, and 98,153 deaths. The north of Thailand has been report as the highest prevalence areas. There were almost 600,000 hill tribe populations live there as a marginalized and vulnerable people under lacked of access to health care and limited education. Most of them emigrated from China last 200 years ago. Chiang Rai Province is the most favorite living area of hill tribe people.

\section{Materials and methods}

The retrospective cohort study design aimed to investigates the TB and HIV situation among hill tribe marginalized and vulnerable population. The systematic data collection with the completed questionnaire was conducted in the 12 hospitals, Chiang Rai Province. All questionnaires had been tested for reliability and validity before use. Survival and Cox's regression were analysis.

\section{Results}

Of 629 cases of TB reported during 2009-2011 form 12 hospitals were recruited into the study. $60.7 \%$ were male 23.8\% aged 51-60 years old, and followed by 41-50 years old $(20.2 \%)(\min =1, \max =93)$. Of $84.6 \%$ were pulmonary TB and extra pulmonary $15.4 \%, 44.6 \%$ recieving AFB testing, $77.4 \%$ new cases. The results of treatment found that $22.7 \%$ were cure, $28.6 \%$ complte, $4.3 \%$ defults, $8.1 \%$ death, and $1.9 \%$ failure. Prevalence of HIV/AIDS among hill tribe TB cases was $17.2 \%$. Of $88.1 \%$ had treatment on CAT1, and $4.6 \% \mathrm{CAT} 2$, and $2.3 \% \mathrm{CAT} 4$. Male had greater pulmonary TB ( $p$-vale $=0.044)$, and HIV + than female ( $p$-value $=0.023$ ). Survival analysis found that being male (p-value $=0.01)$, non-HIV (p-value $<0.01)$, and CAT1 had greater success treatment. Cox's regression found that

Correspondence: tk2516ms@gmail.com

School of Health Science, Mae Fah Luang University, Chiang Rai Province, Thailand

(c) 2012 Apidechkul; licensee BioMed Central Ltd. This is an Open Access article distributed under the terms of the Creative Commons Attribution License (http://creativecommons.org/licenses/by/2.0), which permits unrestricted use, distribution, and reproduction in any medium, provided the original work is properly cited. only aged 11-20 years old had related to success treatment $(\mathrm{HR}=2.11,95 \% \mathrm{CI}=1.05-4.26)$.

\section{Conclusion}

Active screening program and increasing the rights of access to care are immediate needed for hill tribe vulnerable people for coping TB problem in Thailand.

Published: 25 May 2012

doi:10.1186/1742-4690-9-S1-P88

Cite this article as: Apidechkul: TB and HIV among hill tribe

marginalized vulnerable population, Thailand. Retrovirology 2012 9(Suppl 1):P88.

Submit your next manuscript to BioMed Central and take full advantage of:

- Convenient online submission

- Thorough peer review

- No space constraints or color figure charges

- Immediate publication on acceptance

- Inclusion in PubMed, CAS, Scopus and Google Scholar

- Research which is freely available for redistribution 